\title{
Novel angiotensin l-converting enzyme inhibitory peptides derived from an edible mushroom, Pleurotus cystidiosus O.K. Miller identified by LC-MS/MS
}

Ching Ching Lau ${ }^{1}$, Noorlidah Abdullah ${ }^{1 *}$ and Adawiyah Suriza Shuib ${ }^{1,2}$

\begin{abstract}
Background: Angiotensin I-converting enzyme (ACE) inhibitors have been reported to reduce mortality in patients with hypertension. Compared to chemosynthetic drugs, ACE inhibitors derived from natural sources such as food proteins are believed to be safer for consumption and to have fewer adverse effects. Some edible mushrooms have been reported to significantly reduce blood pressure after oral administration. In addition, mushrooms are known to be rich in protein content. This makes them a potential source of ACE inhibitory peptides. Hence, the objective of the current study was to isolate and characterise ACE inhibitory peptides from an edible mushroom, Pleurotus cystidiosus.
\end{abstract}

Methods: ACE inhibitory proteins were isolated from P. cystidiosus based on the bioassay guided purification steps, i.e. ammonium sulphate precipitation, reverse phase high performance liquid chromatography and size exclusion chromatography. Active fraction was then analysed by LC-MS/MS and potential ACE inhibitory peptides identified were chemically synthesized. Effect of in vitro gastrointestinal digestions on the ACE inhibitory activity of the peptides and their inhibition patterns were evaluated.

Results: Two potential ACE inhibitory peptides, AHEPVK and GPSMR were identified from P. cystidiosus with molecular masses of 679.53 and $546.36 \mathrm{Da}$, respectively. Both peptides exhibited potentially high ACE inhibitory activity with $I_{50}$ values of 62.8 and $277.5 \mu \mathrm{M}$, respectively. SEC chromatograms and BIOPEP analysis of these peptides revealed that the peptide sequence of the hexapeptide, AHEPVK, was stable throughout gastrointestinal digestion. The pentapeptide, GPSMR, was hydrolysed after digestion and it was predicted to release a dipeptide ACE inhibitor, GP, from its precursor. The Lineweaver-Burk plot of AHEPVK showed that this potent and stable ACE inhibitor has a competitive inhibitory effect against ACE.

Conclusion: The present study indicated that the peptides from P. cystidiosus could be potential ACE inhibitors. Although these peptides had lower ACE inhibitory activity compared to commercial antihypertensive drugs, they are derived from mushroom which could be easily obtained and should have no side effects. Further in vivo studies can be carried out to reveal the clear mechanism of ACE inhibition by these peptides.

Keywords: Abalone mushroom, Antihypertensive peptide, Competitive ACE inhibitor

\footnotetext{
* Correspondence: noorlidah@um.edu.my

${ }^{1}$ Mushroom Research Centre, Institute of Biological Sciences, Faculty of Science,

University of Malaya, Kuala Lumpur 50603, Malaysia

Full list of author information is available at the end of the article
} 


\section{Background}

Angiotensin I-converting enzyme (ACE) inhibitors have been reported to reduce mortality in patients with hypertension [1]. These drugs act as vasodilators by reducing the levels of angiotensin II in the reninangiotensin system or by inhibiting the degradation of bradykinin in the kallikrein-kinin system [2]. They have been prescribed as first-line treatment for hypertension in patients with type 1 diabetes, proteinuria or left ventricular systolic dysfunction (LVSD) [3]. Captopril was the first orally active ACE inhibitor to be synthesised [4]. Compared to chemosynthetic drugs, ACE inhibitory peptides derived from natural sources such as food proteins are believed to be safer for consumption and to have fewer adverse effects. Many ACE inhibitory peptides have been isolated from food proteins such as salmon, tuna, rice, buckwheat, soybean and whey [5-10]. Some of these ACE inhibitory peptides have exhibited stability against gastrointestinal digestion and produce a blood pressure-lowering effect when tested in vivo $[6,8]$.

Mushrooms have received increasing attention in recent years because of their health-stimulating properties and medicinal effects. Some edible mushrooms have been reported to significantly reduce blood pressure after oral administration. Examples are Pleurotus cornucopiae, Lyophyllum decastes, P. nebrodensis, Grifola frondosa, P. sajor-caju and Lentinula edodes [11-16]. The protein content in mushrooms is ranked below most animal meats but above most other foods, such as milk, vegetables and fruits [17]. Thus, this makes them a good starting material for the identification of peptides with biological activities including ACE inhibition activity. ACE inhibitory peptides have been successfully purified from edible mushrooms, such as G. frondosa, P. cornucopiae, Pholiota adiposa and Tricholoma giganteum [18-21]. Among the most common edible mushrooms available in Malaysia, P. cystidiosus has exhibited the most potent ACE inhibitory activity. Proteomic analysis of P. cystidiosus has shown that it contains potential ACE inhibitory peptides [22]. Therefore, the objective of the current study was to isolate and characterise ACE inhibitory peptides from P. cystidiosus.

\section{Methods}

\section{Materials}

Sporocarps (or fruiting bodies) of P. cystidiosus were obtained from Gano Farm Sdn. Bhd. and authenticated by morphology and molecular methods by experts in the Mushroom Research Centre, University of Malaya, Malaysia. Herbarium voucher specimen (KLU-M 1234) was deposited in the Kuala Lumpur Herbarium, University of Malaya. Culture for this species was deposited at Mushroom Research Centre culture collection, University of Malaya and was assigned a culture code (KUM 61204).
All solvents and chemicals used in this study were of analytical and HPLC grade. Acetonitrile and trifluoroacetic acid (TFA) were obtained from Merck (Darmstadt, Germany). ACE from rabbit lung, hippuryl-L-histidylL-leucine (HHL) and gastrointestinal proteases (pepsin, trypsin and $\alpha$-chymotrypsin) were purchased from SigmaAldrich (St. Louis, MO, USA).

\section{Purification of potential ACE inhibitory peptides by size exclusion chromatography (SEC)}

Protein extraction from $P$. cystidiosus was done based on a previous study [22]. Briefly, $1000 \mathrm{~g}$ of fresh fruiting bodies of $P$. cystidiosus were cleaned, sliced and blended with distilled water at a ratio of $1: 2(\mathrm{w} / \mathrm{v})$. The mixture was filtered and centrifuged to remove unwanted debris. Proteins were precipitated out from the water extract using ammonium sulphate at $10-100 \%$ salt saturation. Precipitated proteins showing the highest ACE inhibitory activity were then fractionated by reverse phase high performance liquid chromatography (RPHPLC). Based on the results reported by Lau et al., [22], the active RPHPLC fraction was E5PcF3. Thus, it was further purified in the current study by SEC using a Biosep SEC-S2000 column $(300 \times 7.8 \mathrm{~mm}$, Phenomenex, Torrance, CA, USA). Analysis was performed by injecting $20 \mu \mathrm{l}$ of E5PcF3 on an HPLC system equipped with an SCL10AVP system controller, LC-10ATVP solvent delivery unit, SPD-M10AVP UV-vis diode array detector and DGU-12A degasser (Shimadzu, Kyoto, Japan). The mobile phase consisted of $45 \%$ acetonitrile containing $0.1 \%$ TFA. The flow rate was $1.0 \mathrm{ml} / \mathrm{min}$ and the effluent was monitored at $214 \mathrm{~nm}$. E5PcF3 was fractionated according to the peaks obtained. After repeated injections, the fractions collected were freeze-dried and the ACE inhibitory activity of the SEC fractions was determined at a concentration of $1 \mu \mathrm{g} / \mathrm{ml}$ protein. The SEC fraction with the highest ACE inhibitory activity was analysed by liquid chromatography mass spectrometry for sequence identification.

\section{Estimation of the protein content in the SEC protein fraction}

The protein content of the SEC fractions was estimated using the Pierce ${ }^{\circledast}$ Bicinchoninic Acid (BCA) Protein Assay Kit (Thermo Scientific, Rockford, IL, USA) according to the protocol provided by the manufacturer. The absorbance values were measured using a Sunrise ${ }^{\mathrm{TM}}$ ELISA microplate reader (Tecan, Grödig, Austria) at $562 \mathrm{~nm}$. The protein content was determined by comparing the absorbance value of the samples with a standard curve of bovine serum albumin.

\section{Assay of ACE inhibitory activity}

In the current study, ACE inhibitory activity was determined using an ACE inhibitory assay kit (ACE kit-WST, 


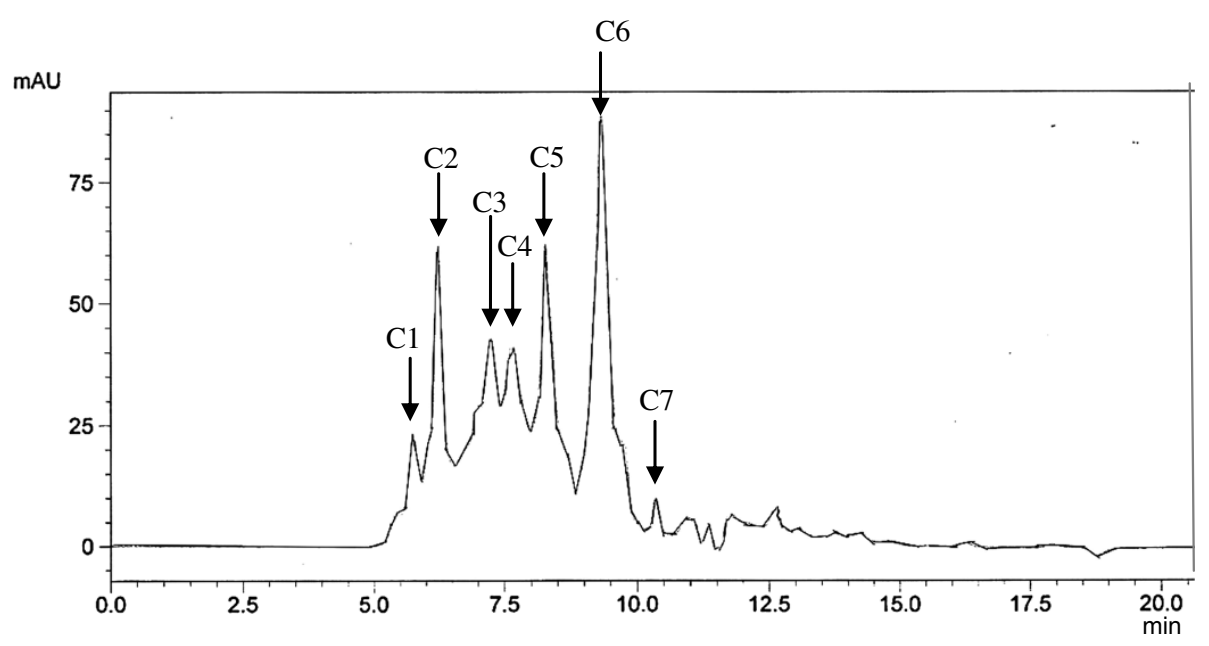

Figure 1 SEC chromatogram of E5PcF3. Following RPHPLC, active protein E5PCF3 was further separated using a Biosep SEC-S2000 column $(300 \times 7.8 \mathrm{~mm})$. The mobile phase consisted of $45 \%$ acetonitrile containing $0.1 \%$ TFA eluted at a flow rate of $1.0 \mathrm{ml} / \mathrm{min}$. Seven peaks eluted from SEC column labelled C1 to C7 were collected and re-evaluated for ACE inhibitory activity.

Dojindo Laboratories, Kumamoto, Japan). The assay was carried out according to the protocol provided by the manufacturer. Absorbances of the reactions were measured using a Sunrise ${ }^{\oplus}$ ELISA microplate reader (Tecan, Grödig, Austria) at $450 \mathrm{~nm}$. The ACE inhibitory activity of the samples was calculated using the formula given in the protocol. The concentration of the ACE inhibitor required to inhibit $50 \%$ of ACE activity under the above assay conditions was defined as the $\mathrm{IC}_{50}$.

\section{Liquid chromatography-mass spectrometry (LC-MS/MS)}

Identification of the peptide sequences present in SEC fraction 1 was carried out by LC-MS/MS at Proteomics International Pty Ltd, WA, Australia. Briefly, the SEC fraction was digested with trypsin and the peptides extracted were analysed by electrospray ionisation mass spectrometry using an Ultimate 3000 nano HPLC system (Dionex, Sunnyvale, CA, USA) coupled to a 4000 QTRAP mass spectrometer (Applied Biosystems, Foster City, CA, USA). Peptides were loaded onto a C18 PepMap100, $3 \mu \mathrm{m}$ (LC Packings) column and separated with a linear gradient of water/acetonitrile/0.1\% formic acid (v/v). Protein identification was carried out using Mascot sequence matching software (Matrix Science) with the Ludwig NR database.

\section{Peptide synthesis}

The two identified potential ACE inhibitory peptides, AHEPVK and GPSMR were chemically synthesised by Peptron, Inc., Republic of Korea. The purity of the synthesised peptides was $>98 \%$ measured by RPHPLC and MS analysis.

\section{Effect of simulated gastrointestinal digestion on the} selected peptides

The stability of the synthesised peptides against gastrointestinal proteases was assessed in vitro by the method of $\mathrm{Wu}$ and Ding [23]. The peptide solution $(0.1 \mathrm{mg} / \mathrm{ml}$, $0.5 \mathrm{ml}$ ) was incubated with $0.5 \mathrm{ml}$ of a $0.05 \%$ pepsin solution $(0.1 \mathrm{M} \mathrm{HCl}$ at $\mathrm{pH} 2.0)$ for $2.5 \mathrm{hrs}$ at $37^{\circ} \mathrm{C}$. In the successive pepsin-pancreatin digestion test, the peptide solution was adjusted to $\mathrm{pH} 8.0$ after pepsin digestion. Then, $0.5 \mathrm{ml}$ of pancreatin solution [potassium phosphate buffer $(0.1 \mathrm{M}, \mathrm{pH} 8.0)$ containing $0.025 \%(\mathrm{w} / \mathrm{v})$ chymotrypsin and $0.025 \%(\mathrm{w} / \mathrm{v})$ trypsin] was added to the solution. The mixture was incubated for another $2.5 \mathrm{hrs}$ at $37^{\circ} \mathrm{C}$. The control (without digestion) consisted of peptide solution incubated in buffer solutions $(\mathrm{HCl}$ and potassium phosphate buffer) and was carried out alongside the experiment. After enzymatic treatment,

Table 1 Percentages of protein recovery yield and percentages of ACE inhibitory activity of the SEC fractions

\begin{tabular}{ccc}
\hline SEC fraction & \% Recovery & \% ACE inhibitory activity \\
\hline C1 & $\mathbf{3 . 6}$ & $\mathbf{2 7 . 4 4} \pm \mathbf{2 . 6 6 ~ \mathbf { ~ }}$ \\
C2 & 3.9 & $5.56 \pm 2.18 \mathrm{a}$ \\
C3 & 24.6 & $7.47 \pm 0.82 \mathrm{a}$ \\
C4 & 12.8 & $7.98 \pm 4.72 \mathrm{a}$ \\
C5 & 9.6 & $5.93 \pm 2.24 \mathrm{a}$ \\
C6 & 12.3 & $8.70 \pm 2.54 \mathrm{ab}$ \\
C7 & 16.6 & $13.60 \pm 3.99 \mathrm{~b}$ \\
Total & 83.4 & - \\
\hline
\end{tabular}

${ }^{*}$ ACE inhibitory activity of SEC fractions was tested at $1 \mu \mathrm{g} / \mathrm{ml}$ protein and expressed as mean \pm standard deviation $(n=3)$. Different letters within a column indicate significant differences $(p<0.05)$ in the percentage of ACE inhibitory activity analysed by one-way ANOVA. SEC fraction highlighted in bold was selected for further analysis. 
the pepsin solution and pepsin-pancreatin solution were boiled for $10 \mathrm{~min}$ to stop the digestion and then centrifuged at 10,000 rpm for $10 \mathrm{~min}$. The supernatants were freeze-dried and used for the measurement of ACE inhibitory activity. The stability of the purified peptides against gastrointestinal enzymes was analysed by SEC.

\section{Determination of the inhibition pattern on ACE activity}

The inhibition pattern of peptide AHEPVK on ACE activity was determined spectrophotometrically using
HHL as substrate. Basically, $20 \mu \mathrm{l}$ of the ACE solution $(0.1 \mathrm{UN} / \mathrm{ml})$ and $50 \mu \mathrm{l}$ of peptide were incubated with $200 \mu \mathrm{l}$ of various HHL concentrations $(0.63,1.25,2.50$ and $5.00 \mathrm{mM})$. The enzymatic reaction was terminated by the addition of $250 \mu \mathrm{l}$ of $1.0 \mathrm{M} \mathrm{HCl}$. The liberated hippuric acid was extracted with ethyl acetate and evaporated under vacuum condition. The hippuric acid residue was re-dissolved in $1.0 \mathrm{ml}$ of distilled water and the absorbance was determined at $228 \mathrm{~nm}$ using a spectrophotometer (SmartSpec ${ }^{\mathrm{Tm}}$ Plus Spectrophotometer,




Bio-Rad Laboratories, Hercules, USA). The enzyme activities were measured in the presence $(0.05$ and $0.50 \mathrm{mg} / \mathrm{ml})$ and absence (control) of peptide. The kinetic of ACE inhibition was determined by Lineweaver-Burk plots.

\section{Statistical analysis}

The analysis of ACE inhibitory activity was carried out in triplicate and result was reported as mean \pm standard deviation. Mean differences of ACE inhibitory activity in SEC fractions was analyzed using one-way ANOVA in Statgraphics Plus 3.0 at $\mathrm{p}<0.05$.

\section{Results and discussion}

Purification of potential ACE inhibitory peptides by SEC

The RPHPLC fraction of E5PcF3 was further fractionated by SEC into seven fractions ( $\mathrm{C} 1$ to $\mathrm{C} 7)$, as shown in Figure 1. Referring to Table 1, a total of $83.4 \%$ of the proteins were recovered by SEC. The percentages of protein collected from fractions $\mathrm{C} 1$ to $\mathrm{C} 7$ were in the range of 3.6 to $24.6 \%$. Each SEC fraction was tested for ACE inhibitory activity at a concentration of $1 \mu \mathrm{g} / \mathrm{ml}$. Among the seven SEC fractions, $\mathrm{C} 1$ exhibited significantly higher ACE inhibitory activity, where $27.44 \%$ of ACE enzyme activity was blocked. Therefore, $\mathrm{C} 1$ was selected for further analysis by LC-MS/MS.

\section{Identification of ACE inhibitory peptide by LC-MS/MS}

The amino acid sequences of the peptides in $\mathrm{C} 1$ were determined by LC-MS/MS. Two potential ACE inhibitory peptides were identified. The LC-MS/MS spectra of these peptides are shown in Figure 2. Peptides AHEPVK and GPSMR had molecular masses of 679.53 and $546.36 \mathrm{Da}$, respectively. A low molecular weight is an added advantage for a potent ACE inhibitor because large peptide molecules are restricted from fitting into the active site of ACE [24]. Interestingly, the two peptides in the current study were found to have similar sequence compared to ACE inhibitory peptides from other food sources. For instance, similar to AHEPVK, potential ACE inhibitor from sea squirt (AHIII) has alanine and histidine at the N-terminal [25]. GPSMR has similar peptide sequence with peptide from sweet potato (GPCSR) [26].

In the current study, peptide AHEPVK exhibited potentially high $\mathrm{ACE}$ inhibitory activity with an $\mathrm{IC}_{50}$ value of $62.8 \mu \mathrm{M}$. This is lower than the $\mathrm{IC}_{50}$ value of $\mathrm{ACE}$ inhibitory peptides isolated from other edible mushrooms, i.e. G. frondosa $(129.7 \mu \mathrm{M}), P$. adiposa $(254 \mu \mathrm{M})$ and P. cornucopiae $(277.3 \mu \mathrm{M})[18,20,21]$. On the other hand, peptide GPSMR inhibited 50\% of ACE activity at a concentration of $277.5 \mu \mathrm{M}$, which is similar to the $\mathrm{IC}_{50}$ values of $P$. adiposa and $P$. cornucopiae $[18,20]$.

The peptides in the current study have lower ACE inhibitory activity than proteins from other food sources. Hexapeptide from milk (PYVRYL) and pentapeptide from bonita fish (LKPNM) have exhibited $\mathrm{IC}_{50}$ value of $2.4 \mu \mathrm{M}[27,28]$. Peptide LRIPVA from spinach inhibited $50 \%$ of the ACE at a concentration as low as $0.38 \mu \mathrm{M}$ [29]. However, there were also studies reported on similar $\mathrm{IC}_{50}$ value with the current study. Peptides GTEKC and GPCSR from sweet potato exhibited $\mathrm{IC}_{50}$ values of 61.67 and $275.8 \mu \mathrm{M}$, respectively [26,30].

There are several ACE inhibitory peptides from food sources that have been sold in Japan and Canada. Examples are Vasotensin ${ }^{\circ}$, PeptACE $^{\mathrm{Tm}}$ and Valtyron ${ }^{\circ}$ [31]. These products were claimed to be suitable for treating mild hypertension and free of side effects [32,33]. This may suggest that ACE inhibitors from natural sources can

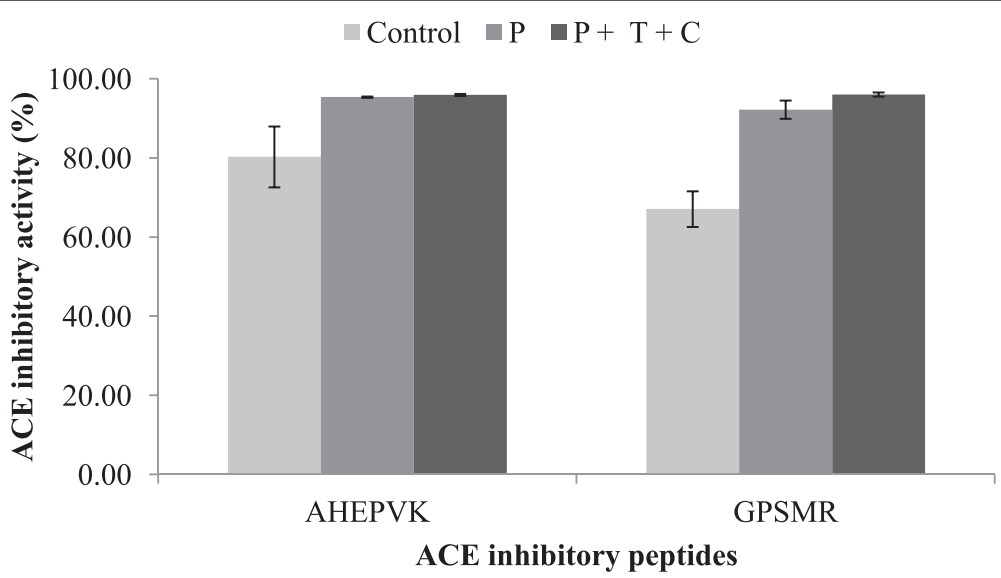

Figure 3 Effect of simulated gastrointestinal digestion on the ACE inhibitory activity of peptides AHEPVK and GPSMR. Control: The peptide solutions $(0.1 \mathrm{mg} / \mathrm{ml})$ were incubated in buffer solutions ( $\mathrm{HCl}$ and potassium phosphate buffer). P: The peptide solutions were incubated with $0.05 \%$ pepsin solution for $2.5 \mathrm{hrs}$ at $37^{\circ} \mathrm{C} . \mathrm{P}+\mathrm{T}+\mathrm{C}$ : The peptide solutions were successively digested with pepsin for $2.5 \mathrm{hrs}$. They were further incubated in pancreatin solution for another $2.5 \mathrm{hrs}$ at $37^{\circ} \mathrm{C}$. The ACE inhibitory activity are expressed as mean \pm standard deviation $(\mathrm{n}=3$ ). 
be a good alternative to synthetic drugs which are known to cause side effects such as cough, skin rashes, taste disturbance and angioedema [34]. Even though peptides from edible mushrooms have lower ACE inhibitory activity compared to peptides from other food sources, in vivo studies of peptides from mushrooms, $P$. adiposa and $P$. cornucopiae have shown similar antihypertensive effect with the commercial drug, captopril $[18,20]$. Additionally, mushrooms have an added advantage of low probability to cause food allergy. Therefore, the peptides tested in the current study, particularly AHEPVK could be applied as ingredient in functional foods, dietary supplements or pharmaceuticals as an antihypertensive agent.



Figure 4 Stability of peptide AHEPVK against gastrointestinal enzymes observed by SEC chromatograms. Separation was performed on a Biosep SEC-S2000 column $(300 \times 7.8 \mathrm{~mm})$. Mobile phase consisted of $45 \%$ acetonitrile containing $0.1 \%$ TFA eluted at a flow rate of $1.0 \mathrm{ml} / \mathrm{min}$. Peptide was eluted as peak at retention time illustrated in the box. A: Pure peptide; $\mathbf{B}$ : The peptide solution (0.1 $\mathrm{mg} / \mathrm{ml})$ was incubated in buffer solutions (control); C: The peptide solution was incubated with $0.05 \%$ pepsin solution for $2.5 \mathrm{hrs}$ at $37^{\circ} \mathrm{C}$; $\mathbf{D}$ : The peptide solution was successively digested with pepsin for $2.5 \mathrm{hrs}$. They were further incubated in pancreatin solution for another $2.5 \mathrm{hrs}$ at $37^{\circ} \mathrm{C}$. 


\section{Effect of simulated gastrointestinal digestion on the selected peptides}

Proteins or peptides delivered by the oral route have to be able to maintain their biological activity throughout the digestion process in the gastrointestinal tract before they reach their target site inside the body. The most important sites for the digestion of proteins and peptides are the stomach and small intestine. They contain gastrointestinal enzymes such as pepsin (stomach), trypsin and chymotrypsin (small intestine) [35]. Preliminary experiments using gastrointestinal enzyme incubation in vitro provided an easy method to evaluate the fate of these peptides after oral administration.

Referring to Figure 3, both peptides had exhibited high ACE inhibitory activity after gastrointestinal digestion. Without gastrointestinal digestion, AHEPVK inhibited

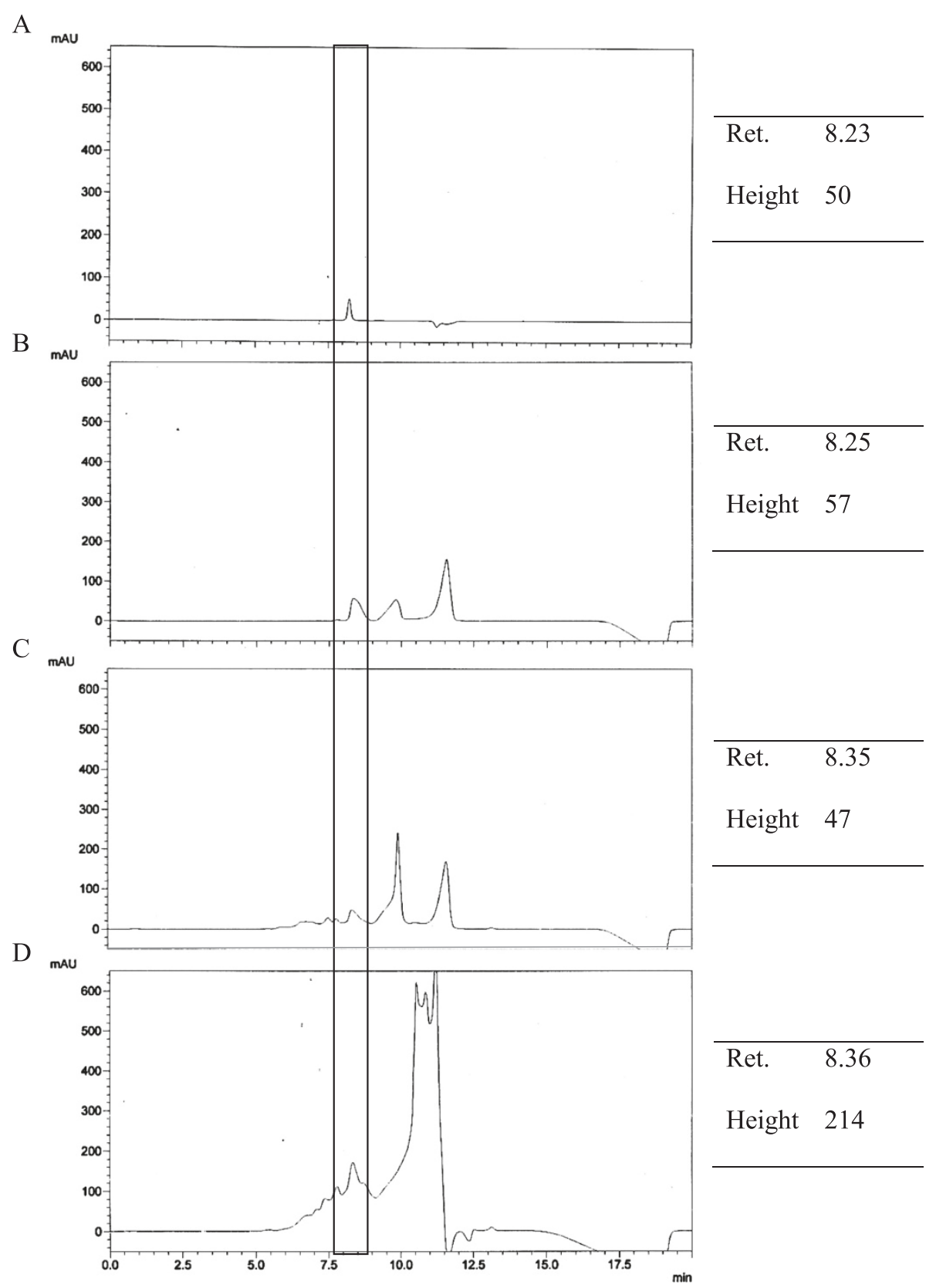

Figure $\mathbf{5}$ Stability of peptide GPSMR against gastrointestinal enzymes observed by SEC chromatograms. Separation was performed on a Biosep SEC-S2000 column $(300 \times 7.8 \mathrm{~mm})$. Mobile phase consisted of $45 \%$ acetonitrile containing $0.1 \%$ TFA at a flow rate of $1.0 \mathrm{ml} / \mathrm{min}$. Peptide was eluted as peak at retention time illustrated in the box. A: Pure peptide; $\mathbf{B}$ : The peptide solution $(0.1 \mathrm{mg} / \mathrm{ml})$ was incubated in buffer solutions (control); C: The peptide solution was incubated with $0.05 \%$ pepsin solution for $2.5 \mathrm{hrs}$ at $37^{\circ} \mathrm{C} ; \mathbf{D}$ : The peptide solution was successively digested with pepsin for $2.5 \mathrm{hrs}$. They were further incubated in pancreatin solution for another $2.5 \mathrm{hrs}$ at $37^{\circ} \mathrm{C}$. 
$80.27 \%$ of ACE activity. Its activity was enhanced to $95.38 \%$ after digestion by pepsin and maintained at 95.94\% after pepsin-pancreatin digestion. Compared to AHEPVK, GPSMR exhibited greater enhancement after digestion. The ACE inhibitory activity increased from $67.08 \%$ to $92.22 \%$ after digestion by pepsin. Pepsinpancreatin digestion further enhanced the ACE inhibitory activity to $96.05 \%$. Previous studies have reported on peptides which were resistant to further gastrointestinal digestion and maintain their biological activity after digestion [36]. However, some peptides could undergo further hydrolysis by gastrointestinal enzymes to release true inhibitors [37].

In order to verify the stability of these peptides, the changes without and following gastrointestinal digestion were analysed by SEC. The chromatograms are illustrated in Figures 4 and 5. Peaks for buffer $(\mathrm{HCl}$ and potassium phosphate buffer) were eluted at approximately 9 and $11 \mathrm{~min}$. This may explained the detection of two extra peaks in the chromatograms. The BIOPEP database (http://www.uwm.edu.pl/biochemia/index.php/ en/biopep) is an online program that can serve as a tool to predict possible proteolysis products by gastrointestinal enzymes and define the possible biological activity of the proteolysis fragments [38]. Therefore, the predicted proteolysis activity analysed by the BIOPEP database was compared with the SEC chromatograms of AHEPVK and GPSMR in the current study.

According to BIOPEP, AHEPVK was not hydrolysed by the three proteolytic enzymes. It was predicted to remain stable throughout the digestion process. Referring to Figure 4, the peptide AHEPVK, which was eluted at $7.80 \mathrm{~min}$, showed high intensity in the SEC chromatograms of the control and after digestion. This confirmed the stability of AHEPVK against digestive enzymes. Additionally, Wang et al. [39] have reported that the preferential parameters for hexapeptides with potent ACE inhibitory activity are stereo and hydrophobic properties. Jimsheena and Gouda had shown the important role of stereo-specificity of amino acid residue in ACE inhibitory activity. Based on their study, tripeptide IKP that contained L-lysine exhibited potent ACE inhibitory activity. However, replacement of the Llysine with D-lysine caused the peptide to lose its ACE inhibitory property [40]. Hydrophobicity of amino acids has been indicated to have the greatest influence on ACE inhibitory activity. According to Pripp and co workers, hydrophobicity of C-terminal enhanced the ACE inhibitory activity of potential peptides up to six amino acids in length [41]. In the current study, the stereoisomer effect of AHEPVK on ACE inhibition was not definitive due to the unknown stereo structure of the synthesized peptide. However, based on the peptide sequence, hydrophobicity may have contributions in the high ACE inhibitory activity of AHEPVK both before and after digestion.

Referring to Figure 5, the peptide peak of GPSMR at a retention time of $8.23 \mathrm{~min}$ was shifted and became broader after gastrointestinal digestion. Theoretically, smaller peptides would be eluted from the SEC column at a later time [42]. This may suggest that the peptide GPSMR had been hydrolysed into smaller fragments that were eluted together with gastrointestinal enzymes, resulting in a broad peak at $8.36 \mathrm{~min}$. This is in line with the results obtained by BIOPEP analysis. According to the database, GPSMR was predicted to release fragments of GP, SM and R from its precursor after gastrointestinal digestion. Interestingly, dipeptide GP has been previously reported to exhibit ACE inhibitory activity with an $\mathrm{IC}_{50}$ value of $252.63 \mu \mathrm{M}$ [43]. Therefore, the enhanced ACE inhibitory activity of GPSMR after gastrointestinal digestion was most probably due to the release of GP.



Figure 6 Kinetics of the synthetic peptide AHEPVK. ACE inhibitory activity was determined in the absence and presence of different concentrations of the peptides $(0.00,0.05$ and $0.50 \mathrm{mg} / \mathrm{ml})$. Lineweaver-Burk plot was constructed using values of $1 / \mathrm{V}$ against $1 /$ [S]. Values are expressed as mean \pm standard deviation $(n=3)$. 


\section{Inhibition pattern of ACE inhibitors}

Peptide AHEPVK exhibited the most potent ACE inhibitory activity $\left(\mathrm{IC}_{50} 62.8 \mu \mathrm{M}\right)$ and it shows stability against gastrointestinal digestion. Therefore, it was selected to determine its inhibition pattern against the ACE enzyme. According to the Lineweaver-Burk plot in Figure 6, peptide AHEPVK showed a competitive inhibition pattern against the ACE. This suggests that the peptide might bind to the active site of ACE to block it from binding to the substrate. Moreover, ACE has been reported to show preference for competitive inhibitors that contain a hydrophobic amino acid at the third position from the C-terminal $[44,45]$. This is in accordance with the amino acid sequence of AHEPVK which might explain the competitive inhibition pattern exhibited by this peptide.

The competitive inhibition pattern exhibited by AHEPVK is similar to ACE inhibitory peptides purified from the edible mushrooms G. frondosa, P. cornucopiae, P. adiposa and T. giganteum [18-21]. In addition, a commercial ACE inhibitor and antihypertensive drug, captopril, also inhibits ACE in a competitive manner [4].

\section{Conclusion}

In the current study, peptides isolated from $P$. cystidiosus were shown to be potential ACE inhibitors. Peptide AHEPVK exhibited a high $\mathrm{IC}_{50}$ value $(62.8 \mu \mathrm{M})$ and its peptide sequence remained stable following gastrointestinal digestion. It exhibited a competitive inhibition pattern against ACE. Peptide GPSMR was predicted to release a dipeptide ACE inhibitor, GP, from its precursor after gastrointestinal digestion. Although these peptides had lower ACE inhibitory activity compared to commercial antihypertensive drugs, they are derived from food sources and should have no side effects.

\section{Abbreviations}

ACE: Angiotensin I-converting enzyme; RPHPLC: Reverse phase high performance liquid chromatography; SEC: Size exclusion chromatography: LC-MS/MS: Liquid chromatography mass spectrometry.

\section{Competing interests}

The authors declare that they have no competing interests.

\section{Authors' contributions}

CCL carried out all the experimentation, analysis of data and drafting of the manuscript. NA involved in monitoring and coordinating the work on mushroom biology and antihypertensive activity. ASS involved in coordinating the work on isolation and purification of peptides; and proteomic analysis. All authors read and approved the final manuscript.

\section{Acknowledgements}

The authors would like to thank the University of Malaya (Grant PPP: PS238/ 2008C, PS478/2010B, PV073-2011B) and the Ministry of Higher Education Malaysia (HIR-MOHE: F000002-21001) for financial support for this project.

\section{Author details}

${ }^{1}$ Mushroom Research Centre, Institute of Biological Sciences, Faculty of Science, University of Malaya, Kuala Lumpur 50603, Malaysia. ${ }^{2}$ Medical Biotechnology Laboratory, University of Malaya Centre for Proteomics Research (UMCPR), Faculty of Medicine, University of Malaya, Kuala Lumpur 50603, Malaysia.
Received: 19 March 2013 Accepted: 6 November 2013

Published: 11 November 2013

\section{References}

1. van Vark LC, Bertrand M, Akkerhuis KM, Brugts JJ, Fox K, Mourad J-J, Boersma E: Angiotensin-converting enzyme inhibitors reduce mortality in hypertension: a meta-analysis of randomized clinical trials of renin-angiotensin-aldosterone system inhibitors involving 158998 patients. Eur Heart J 2012, 33:2088-2097.

2. Erdös EG: The ACE and I: how ACE inhibitors came to be. FASEB J 2006, 20(8):1034-1038.

3. Flint $\mathrm{L}$ : The role of ACE inhibitor therapy in treating cardiovascular disease. Nurs Times 2004, 100(12):34-36.

4. Bhuyan BJ, Mugesh G: Angiotensin converting enzyme inhibitors in the treatment of hypertension. Curr Sci 2011, 101(7):881-887.

5. Ma M-S, Bae IY, Lee HG, Yang C-B: Purification and identification of angiotensin I-converting enzyme inhibitory peptide from buckwheat (Fagopyrum esculentum Moench). Food Chem 2006, 96(1):36-42.

6. Li G-H, Qu M-R, Wan J-Z, You J-M: Antihypertensive effect of rice protein hydrolysate with in vitro angiotensin I-converting enzyme inhibitory activity in spontaneously hypertensive rats. Asia PaC J Clin Nutr 2007, 16(Suppl 1):275-280

7. Rho SJ, Lee J-S, Chung Yl, Kim Y-W, Lee HG: Purification and identification of an angiotensin l-converting enzyme inhibitory peptide from fermented soybean extract. Process Biochem 2009, 44:490-493.

8. Lee S-H, Qian Z-J, Kim S-K: A novel angiotensin I converting enzyme inhibitory peptide from tuna frame protein hydrolysate and its antihypertensive effect in spontaneously hypertensive rats. Food Chem 2010, 118:96-102.

9. Gu R-Z, Li C-Y, Liu W-Y, Yi W-X, Cai M-Y: Angiotensin I-converting enzyme inhibitory activity of low-molecular-weight peptides from Atlantic salmon (Salmo salar L.) skin. Food Res Int 2011, 44:1536-1540.

10. Tavares T, Contreras MM, Amorim M, Pintado M, Recio I, Malcata FX: Novel whey-derived peptides with inhibitory effect against angiotensinconverting enzyme: In vitro effect and stability to gastrointestinal enzyme. Peptides 2011, 32:1013-1019

11. Miyazawa N, Okazaki M, Ohga S: Antihypertensive effect of Pleurotus nebrodensis in spontaneously hypertensive rats. J Oleo Sci 2008, 57(12):675-681.

12. Tam SC, Yip KP, Fung KP, Chang ST: Hypotensive and renal effects of an extract of the edible mushroom. Life Sci 1986, 38(13):1155-1161.

13. Wasser SP: Shiitake. In Encyclopedia of Dietary Supplements. Edited by Coates PM, Blackman MR, Cragg GM, Levine M, Moss J, White JD. USA: Marcel Dekker; 2005:653-664

14. Talpur NA, Echard BW, Fan AY, Jaffari O, Bagchi D, Preuss HG: Antihypertensive and metabolic effects of whole Maitake mushroom powder and its fractions in two rat strains. Mol Cell Biochem 2002, 237(1):129-136.

15. Hagiwara S-Y, Takahashi M, Shen Y, Kaihou S, Tomiyama T, Yazawa M, Tamai Y, Sin Y, Kazusaka A, Terazawa M: A phytochemical in the edible Tamogi-take mushroom (Pleurotus cornucopiae), D-Mannitol, inhibits ACE activity and lowers the blood pressure of spontaneously hypertensive rats. Biosci., Biotech., Biochem 2005, 69(8):1603-1605.

16. Kokean $Y$, Nishii $T$, Sakakura $H$, Furuichi $Y$ : Effect of frying with edible oil on antihypertensive properties of Hatakeshimeji (Lyophyllum decastes Sing.) mushroom. Food Sci Technol Res 2005, 11(3):339-343.

17. Chang S-T, Miles PG: Mushrooms: Cultivation, Nutritional Value, Medicinal Effect and Environmental Impact. 2nd edition. Washington, D.C.: CRC Press; 2004

18. Jang J-H, Jeong S-C, Kim J-H, Lee Y-H, Ju Y-C, Lee J-S: Characterisation of a new antihypertensive angiotensin I-converting enzyme inhibitory peptide from Pleurotus cornucopiae. Food Chem 2011, 127:412-418.

19. Lee DH, Kim JH, Park JS, Choi YJ, Lee JS: Isolation and characterization of a novel angiotensin I-converting enzyme inhibitory peptide derived from the edible mushroom Tricholoma giganteum. Peptides 2004, 25(4):621-627.

20. Koo K-C, Lee D-Y, Kim J-H, Yu H-E, Park J-S, Lee J-S: Production and characterization of antihypertensive angiotensin I-converting enzyme inhibitor from Pholiota adiposa. J Microbiol Biotechnol 2006, 16(5):757-763.

21. Choi HS, Cho HY, Yang HC, Ra KS, Suh HJ: Angiotensin I-converting enzyme inhibitor from Grifola frondosa. Food Res Int 2001, 34:177-182. 
22. Lau C-C, Abdullah N, Shuib AS, Aminudin N: Proteomic analysis of antihypertensive proteins in edible mushrooms. J Agric Food Chem 2012, 60:12341-12348

23. Wu J, Ding $X$ : Characterization of inhibition and stability of soy-proteinderived angiotensin I-converting enzyme inhibitory peptides. Food Res Int 2002, 35:367-375

24. Natesh R, Schwager SLU, Sturrock ED, Acharya KR: Crystal structure of the human angiotensin-converting enzyme-lisinopril complex. Nature 2003, 421:551-554.

25. Ko S-C, Lee J-K, Byun H-G, Lee S-C, Jeon Y-J: Purification and characterization of angiotensin l-converting enzyme inhibitory peptide from enzymatic hydrolysates of Styela clava flesh tissue. Process Biochem 2011, 47(1):34-40.

26. Huang G-J, Lu T-L, Chiu C-S, Chen H-J, Wu C-H, Lin Y-C, Hsieh W-T, Liao J-C, Sheu M-J, Lin Y-H: Sweet potato storage root defensin and its tryptic hydrolysates exhibited angiotensin converting enzyme inhibitory activity in vitro. Bot Stud 2011, 52:257-264.

27. Quiros A, Hernandez-Ledesma B, Ramos M, Amigo L, Recio I: Angiotensinconverting enzyme inhibitory activity of peptides derived from caprine kefir. J Dairy Sci 2005, 88:3480-3487.

28. Fujita H, Yoshikawa M: LKPNM: a prodrug-type ACE-inhibitory peptide derived from fish protein. Immunopharmacology 1999, 44:123-127.

29. Yang Y, Marczak ED, Yokoo M, Usui H, Yoshikawa M: Isolation and antihypertensive effect of angiotensin l-converting enzyme (ACE) inhibitory peptides from spinach Rubisco. J Agric Food Chem 2003, 51:4897-4902.

30. Huang G-J, Ho Y-L, Chen H-J, Chang Y-S, Huang S-S, Hung H-J, Lin Y-H: Sweet potato storage root trypsin inhibitor and their peptic hydrolysates exhibited angiotensin converting enzyme inhibitory activity in vitro. Bot Stud 2008, 49:101-108.

31. Harnedy PA, FitzGerald RJ: Bioactive peptides from marine processing waste and shellfish: a review. J Funct Foods 2012, 4:6-24.

32. EFSA Panel on Dietetic Products Nutrition and Allergies: Scientific opinion on the safety of 'sardine peptide product'. EFSA J 2010, 8(7):1684-1700.

33. EFSA Panel on Dietetic Products Nutrition and Allergies: Scientific opinion on the substantiation of health claims related to bonita protein peptide and maintenance of normal blood pressure (ID1716) pursuant to Article 13 (1) of Regulation (EC) No 1924/2006. EFSA J 2010, 8(10):1730-1843.

34. Brown NJ, Vaughan DE: Angiotensin-converting enzyme inhibitors. Circulation 1998, 97:1411-1420.

35. Mahato RI, Narang AS, Thomas L, Miller DD: Emerging trends in oral delivery of peptide and protein drugs. Crit Rev Ther Drug Carrier Syst 2003, 20(2\&3):153-214

36. Sato Y, Toyoda T, Shimizu-lbuka A, Tamura T, Kobayashi-Hattori K, Nakamura T, Arai S, Mura K: Novel angiotensin l-converting enzyme inhibitory peptides found in a thermolysin-treated elastin with antihypertensive activity. Biosci., Biotech., Biochem 2012, 76(7):1329-1333.

37. Li G-H, Le G-W, Shi Y-H, Shrestha S: Angiotensin I-converting enzyme inhibitory peptides derived from food proteins and their physiological and pharmacological effects. Nutr Res 2004, 24:469-486.

38. Iwaniak A, Dziuba J: BIOPEP-PBIL tool for the analysis of the structure of biologically active motifs derived from food proteins. Food Technol Biotechnol 2011, 49(1):118-127.

39. Wang $X$, Wang J, Lin Y, Ding Y, Wang Y, Cheng X, Lin Z: QSAR study on angiotensin-converting enzyme inhibitor oligopeptides based on a novel set of sequence information descriptors. J Mol Model 2011, 17(7):1599-1606.

40. Jimsheena VK, Gouda LR: Arachin derived peptides as selective angiotensin I-converting enzyme (ACE) inhibitors: structure-activity relationship. Peptides 2010, 31:1165-1176.

41. Pripp AH, Isaksson T, Stepaniak L, Sorhaug T, Aldo Y: Qualitative structure activity relationship modelling of peptides and proteins as a tool in food science. Trends Food Sci Technol 2005, 16:484-494.

42. Stanton P: Gel filtration chromatography. In Methods in Molecular Biology HPLC of Peptides and Proteins: Methods and Protocols. Volume 251. Edited by Aguilar M-I. Totowa, NJ: Humana Press Inc; 2004:55-73.

43. Byun H-G, Kim S-K: Structure and activity of angiotensin I converting enzyme inhibitory peptides derived from Alaskan pollack skin. J Biochem Mol Bio 2002, 35(2):239-243.
44. Chel-Guerrero L, Domínguez-Magaña M, Martínez-Ayala A, Dávila-Ortiz G, Betancur-Ancona D: Lima bean (Phaseolus lunatus) protein hydrolysates with ACE-I inhibitory activity. Food Nutr Sci 2012, 3:511-521.

45. Hong F, Ming L, Yi S, Zhanxia L, Yongquan W, Chi L: The antihypertensive effect of peptides: a novel alternative to drugs? Peptides 2008, 29:1062-1071.

doi:10.1186/1472-6882-13-313

Cite this article as: Lau et al.: Novel angiotensin I-converting enzyme inhibitory peptides derived from an edible mushroom, Pleurotus cystidiosus O.K. Miller identified by LC-MS/MS. BMC Complementary and Alternative Medicine 2013 13:313.

\section{Submit your next manuscript to BioMed Central and take full advantage of:}

- Convenient online submission

- Thorough peer review

- No space constraints or color figure charges

- Immediate publication on acceptance

- Inclusion in PubMed, CAS, Scopus and Google Scholar

- Research which is freely available for redistribution

Submit your manuscript at www.biomedcentral.com/submit
C) Biomed Central 